\title{
Synaptosomal-Associated Protein 25
}

National Cancer Institute

\section{Source}

National Cancer Institute. Synaptosomal-Associated Protein 25. NCI Thesaurus. Code C127884.

Synaptosomal-associated protein 25 (206 aa, $\sim 23 \mathrm{kDa}$ ) is encoded by the human SNAP25 gene. This protein plays a role in vesicular transport. 